\title{
REDUCING EMPLOYEE TURNOVER INTENTION
}

\author{
Nazifah Husainah and Azimah Hanifah \\ Faculty of Economics and Business, Universitas Muhammadiyah Jakarta \\ K.H Ahmad Dahlan Street, Cirendeu-Ciputat South Jakarta \\ E-mail: nazifah.husainah@umj,.ac.id ; azimah.hanifah@umj.ac.id
}

\begin{abstract}
Jakarta fluctuations have relatively high. This condition is caused by problems about the intention of earnings, The organization, and the company. The purpose of study is to examine the effect of employee organizations and culture in earnings intention, both directly and indirectly through the organization to an enterprise in foodhall in Jakarta. This method uses a method descriptive and explanations at least 200 samples from the survey respondents from 25 outlets in Jakarta that foodhall. Structural Equation Model data verified by lisrel 8.80 modeling methods of using. The results show that cultures of organization a lively and have high impact significant directly to organizations commitment but has a negative and significant effect directly in circulation intention, commitment organization negative and had an impact a significant impact on earnings intention, the culture of organization negative and had an impact a significant impact on earnings intention through commitment organization. Organization culture and organization commitment simultaneously affect earnings intention. The commitment the organization has more the role of dominant in reducing the level of dropping in and out of employees intention and other based on the survey results was the partial organization mediation about the effects of an organization's culture in circulation intention.
\end{abstract}

Key words: Organizational Culture; Organizational Commitment; Turnover Intention

\section{MENGURANGI INTENSI PERGANTIAN PEGAWAI}

\begin{abstract}
ABSTRAK. Dalam kurun waktu 5 tahun terakhir, turnover karyawan pada perusahaan The FoodHall di DKI Jakarta mengalami fluktuasi yang masih relatif tinggi. Kondisi ini diduga disebabkan oleh masalah yang berkaitan dengan turnover intention, komitmen organisasi dan budaya organisasi pada perusahaan The FoodHall. Tujuan dari studi dalam penelitian ini untuk menguji pengaruh budaya organisasi terhadap turnover intention karyawan baik secara langsung maupun tidak langsung melalui komitmen organisasi pada perusahaan The FoodHall di DKI Jakarta. Penelitian menggunakan metode deskriptif dan eksplanatori survey dengan sampel minimum 200 responden dari 25 gerai The foodhall di DKI Jakarta. Data diverifikasi dengan metode structural equation modeling menggunakan Lisrel 8.80. Hasil penelitian menunjukkan bahwa budaya organisasi berpengaruh positif dan signifikan secara langsung terhadap komitmen organisasi namun berpengaruh negatif dan signifikan secara langsung terhadap turnover intention, komitmen organisasi berpengaruh negatif dan signifikan terhadap turnover intention, budaya organisasi berpengaruh negatif dan signifikan terhadap turnover intention melalui komitmen organisasi. Budaya organisasi dan komitmen organisasi secara simultan berpengaruh terhadap turnover intention. Komitmen organisasi memiliki peranan yang lebih dominan dalam menurunkan turnover intention karyawan, dan temuan lain dari penelitian ini adalah komitmen organisasi merupakan partial mediating pada pengaruh budaya organisasi terhadap niat pergantian.
\end{abstract}

Kata Kunci: Budaya Organisasi; Komitmen Organisasi; Intensi Perganian Pegawai

\section{INTRODUCTION}

At the beginning of 1990, formed in one of Indonesia's supermarkets in 2005, rebranding in the supermarket was renamed into foodhall. In 2014 foodhall has several subsidiaries like foodhall, daily the kitchen, daily the market, kitchen, foodhall, and gourmet. Foodhall can be found in various districts in data DKI-Jakarta. According (Liem, 2018) in Jakarta this time, 25 Foodhall outlets is spread to the whole city of Jakarta.

Based on (Fauzi, 2017), who foodhall 's sales in the capital Jakarta shows that advantage is smaller than a merchant by various products (FMCG, sales, mode equipment, and accessories other demons). Growth the sale of products care of the show the high growth sale or reaching about (10.7\%), from the sale of products you the personal care is about reached $(10.6 \%)$ while the lowest sale is in the growth rates foodhall products which have only reached its sales $(8.4 \%)$. One factor is why make the foodhall the growth rates the bracelets foodhall in Jakarta is because human resources will be by employees turnover, high as shown in the table.1 under.

The foodhall employees however in Jakarta earnings are relatively high average at about $26.17 \%$ every year, meaning that if foodhall has 100 employees in a year, so there are 26 to 27 the employee who has been a high turn over employee each year at foodhall exceeds employee turnover rate at other retailers like a nursing home, personal care and pharmaceutical outlets at only employees average earnings twenty four per year or two \% per month, (APRINDO, 2017). 
Table 1. The FoodHall employee turnover in DKI Jakarta

\begin{tabular}{|c|c|c|c|c|c|c|}
\hline \multirow{3}{*}{$\begin{array}{c}\text { Year } \\
2011\end{array}$} & \multicolumn{2}{|c|}{ Number of Employees } & \multirow{2}{*}{$\begin{array}{l}\text { (initial + final } \\
\text { amount) } / 2\end{array}$} & \multirow{2}{*}{$\begin{array}{c}\text { Number employee } \\
\text { resign/ year }\end{array}$} & \multirow{2}{*}{\multicolumn{2}{|c|}{$\begin{array}{c}\text { Employee Turnover } \\
\text { (\%) }\end{array}$}} \\
\hline & Early year & End year & & & & \\
\hline & 752 & 808 & 780 & 202 & $202 / 780 \times 100 \%=$ & 25,90 \\
\hline 2012 & 808 & 900 & 854 & 227 & $227 / 854 \times 100 \%=$ & 26,58 \\
\hline 2013 & 900 & 1519 & 1210 & 343 & $\begin{array}{c}343 / 1210 \times 100 \% \\
=\end{array}$ & 28,36 \\
\hline 2014 & 1519 & 1927 & 1723 & 478 & $\begin{array}{c}478 / 1723 \times 100 \% \\
=\end{array}$ & 27,74 \\
\hline 2015 & 1927 & 2095 & 2011 & 507 & $\begin{array}{c}507 / 2011 \mathrm{X} \\
100 \%=\end{array}$ & 25,21 \\
\hline 2016 & 2095 & 1982 & 2039 & 496 & $\begin{array}{c}496 / 2039 \times 100 \% \\
=\end{array}$ & 24,33 \\
\hline average & 1334 & 1539 & 1437 & 376 & $\begin{array}{c}376 / 1437 \times 100 \% \\
=\end{array}$ & 26,17 \\
\hline
\end{tabular}

Source: The FoodHall di DKI Jakarta, 2017

According to (Srivastava \& Kanpur, 2014), very important strategy to an organization for designed to improve employee performance factors above so it could be improved and efficiency to reduce turnover, intention statement flattened high turnover flattened workers in company foodhall in Jakarta caused by the relatively high turnover, employees intention this in accordance with the data (Sulmiah, 2017) flattened foodhall stated that employees be a SPG or servant.

Some of them only works in foodhall while waiting for other job opportunities to come. This continuing their studies again, look for other jobs , or even just while waiting for relationship. High turnover foodhall intention of an employee in Jakarta it shows that based on the results from the beginning of survey by the researchers (2017) in a number of foodhall. They showed that employees turnover. Still relatively high intention, employees's intention earnings are, is still relatively high based on intention to find a better position and better.

(Jin, Seo, \& Shapiro, 2016) suggest that pleasure and commitment is negative and significant, relating to employee' intention. (Limakrisna, Noor, \& Ali, 2016) statistics show a significant, relating to stress, experience salary, leadership support, satisfaction the association works, commitment and a willingness to a statement move. statement up there the high sales in Jakarta foodhall workers is caused by the relatively low commitment. Organization that is based on data the survey researchers (2017) in a few foodhall Jakarta showed that level of commitment to workers in Jakarta foodhall organization generally still relatively low.

Relatively low in affective organization commitment always and normative commitment. Practical commitment foodhall low to Jakarta employee who employees who are relatively happy choose other companies as a place for work. So continuously in general low level of commitment employees still felt the absence of conformity of company policy and a lack of loyalty to the low in general. The normative employees still felt a lack of compatibility normally. The study of turnover, all done by (Hakim \& Hadipapo, 2015), said that the organization and the organization the impact of an employee who turnover intention in fast-food industry.

(Telha, Rodrigues, Páscoa, \& Tribolet, 2016) said that the aspect of culture in the organization positively impacts the role and performance behavior in any negative impact on employees intention. Turnover based on this study, low organization commitment and intention high succession than workers Foodhall in Jakarta considered caused by culture organization relatively low.

This is consistent by Aprindo (Fauzi, 2017) who one of a means to reduce income intention employees foodhall this is the role and function of human resource development, how building conducive culture organization and employees feel them has front employees a career in retail industry so income can be reduced so as not to be high. Employees low organization high commitment and intentions of foodhall earnings in Jakarta also indicated based on preliminary survey researchers (2017) in some foodhall shows that in workers organization Jakarta culture, In general, are still relatively low.

Organization, especially in the innovation with, risk-taking the team, orientation, aggressiveness, and stability. Low innovation and take in Foodhall risk in Jakarta as a innovative lack and ideas of creative and a innovations lack. So team-low employee orientation cannot generally work with colleagues. A lack of solving a problem as a team, orientation on teamwork, and is still low. The organization's low culture can be seen from the aggressiveness and stability, a dimension that still lacks in protections. Employees work still low aggressive in monitoring and still low encouraging to work correctly and 
paster. Stability is weak in protecting stability an excellent job and was short on enforce discipline on employees (Kaur, 2015).

\section{The Culture of Organizational}

(Telha et al., 2016) Organization culture understands values and confidence sub units developed in an organization or direct employees who conduct the organization's explanation. (Chu, Leino, Pflum, \& Sue, 2016) argued cultural of organizations explain the right way for preparing, thinking, and feeling in a relationship with one another in the system of social. (Telha et al., 2016) states culture as an organizing framework consisting and attitude, cognitive values, norms, behavior, and sharing the wish by members.

(Cycyota, Ferrante, \& Schroeder, 2016) shows that organizations understand culture value and confidence in identity. (Sagita, Susilo, \& Cahyo, 2018) argued that the organization culture is the number of, the ritual, faith, rules typical of, facts and organizations characterize nation. (Limakrisna \& Juju, 2008) stated that the culture is a system to the meaning of value to the base and valued by, organization which serves to create a clear distinction between one organization and, other makes an identity for the organization members, facilitate the emergence of a commitment to, organization collectively improve stability, social system and create meaning-making control mechanisms and guide the practice of attitudes and behavior team members of organization (Kreitner \& Kinicki, 2014).

According to , there were seven characteristic introductory together can repeat nature and culture organization, 1) innovation and risks, the extent to which employees are is encouraged to be an innovative and risk; 2) attention to detail the extent to which employees expected to show accuracy, analysis, and call attention to detail; 3) from orient, the extent to which the management is focusing on results, not on engineering and the process used to achieve their; 4) orientation, the extent to which management decisions consider the effects of the above the in the organization; 5) orientation the extent to which the team work, held at least not attending individual; 6) aggressiveness, the extent to which aggressive and competitive of relaxed; 7) stability the extent to which the organizations stressed to keep the status quo from Indonesia (S. Robbins \& Judge, 2009).

\section{Organizational Commitment}

(Herawati \& Prayekti, 2017) commitment organization is the extent to which employees believe and receive organizations purpose and a desire to remain with organization. (Buchari, 2016) stated how a commitment organization is an intense desire to be a member of certain organizations, a strong desire to try to conform with an organization, confidence, the value and receiving value in individual and organizational goals. While (Bailey, Albassami, \& Al-Meshal, 2016) commitment organization is a bond psychological employees to the organization that are characterized by the strong beliefs and receipts for the purpose and the values of the organization, desire to accomplish a purpose organization , and a strong desire for maintain a position them as of members of an organization.

(Srivastava \& Kanpur, 2014) stated that the organization to know the level of the employees and organization because of the employees and affect the organization employees. (Mercurio, 2015) see social organization commitment as a willingness to provide energy and loyalty to organizations. The statement shows that commitment is an employee willingness to exert a high level of business at, organization a strong desire to stay with the organization, and the organization goals, mission and values. The same time (Bulut \& Culha, 2010) defines commitment as a situation in which the organization members are bound by the actions and the belief that support their activities and their involvement in the organization. The concept commitment organization defined and measured in different ways.

(Valaei \& Rezaei, 2016) stated that there are three dimensions of the commitment, organization namely the commitment of affective: 1) relating to the desire to bound to organizations or emotional attachment to employees, identification and involved in the organization is going on when employees want to be a part and the organization because of the international relations or feel the same value as the organization; 2) the continued commitment is an awareness of cost to be borne (loss or anything else associated with discharge) employee of the organization; 3) normative commitment is a sense of duty and employees to stay in an organization because feeling a debt to the organization.

\section{Turnover Intention}

According to (Nitzsche, Jung, Kowalski, \& Pfaff, 2014)an instrument for measuring an organizational culture that promotes the work-life balance of employees. Inn \nMETHODS: In Study $1(\mathrm{~N}=498$ the purpose of the enter and leave at employees are tendency have or rate at which an employee can leave his organization or voluntarily resigned from his job and judge. (S. P. Robbins \& Judge, 2017) defines the law permanently cessation 
enter and leave at employees working from the company either by employees he (voluntarily) or done by the company. (Cycyota et al., 2016) the higher satisfaction work and commitment the organization was expected to reduce property and employees to leave those organization.

Also, employees who are dissatisfied with aspects of their work and not committed to the organization are more likely to obtain work in other institutions. (Liden, Wayne, Liao, \& Meuser, 2014) desire to move can be an early symptom of a firm time needed to leave (intention turnover ) employees did can be defined as labour out and organization.

The resignation of intention, earnings can be one a step out of a organizational unit, the dismissal of or death a member of organization. (Chen \& Silverthorne, 2005), see there are three indicators that were used for measuring intention, earnings namely, stop the mind that reflects individual to think outside of stay or work in a work environment; eagerness to obtain a better job the position of (a more favourable position to give that reflects the individual to find a job for a better job a position in other organization); looking for a job and a desire to which is the best a better job to resign from that reflects the individual that is intend to leave. Employees intending to go if they find a better job, sooner or later we ended up with employee's the decision to fixed or resigned from his job.

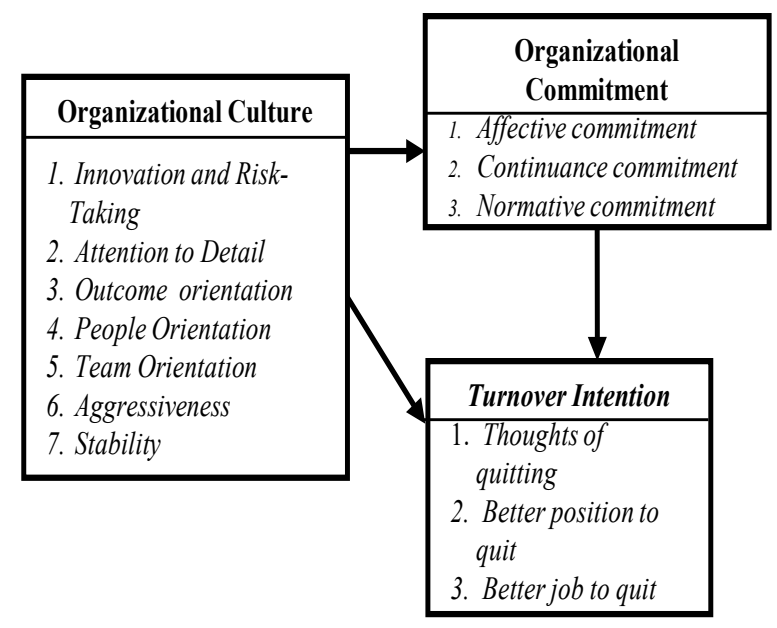

Figure1. Organizational Commitment

Based on the description of the figure 1 and referring to the research model above, the research hypothesis is:

H1: There is a cultural influence of the organization on the organization's commitment and the intention of turnover to FoodHall employees in DKI Jakarta.

$\mathrm{H} 2$ : There is an influence of the organization's commitment to turnover intentions on FoodHall employees in DKI Jakarta.
H3: There is an organizational culture towards employee turnover intention through the organization's commitment to FoodHall employees in DKI Jakarta.

H4: There are organizational culture and organizational commitment simultaneously to turnover intention in The FoodHall employees in DKI Jakarta

\section{METHOD}

The method used in this study is the survey and associative explanation descriptive methods with techniques. This study using two method of surveying, Namely descriptive survey and explanatory survey. Analysis units in this study is an employee at 25 foodhall outlets in Jakarta. This study time horizon is an organization. Sample is at once to be performed. For get perception data from respondents response associated with variable, research each variable, consisting of the dimensions which then operationalized against indicators.

Research operationalitation variables is as follows: 1. organization culture, measured by uses seven dimensions with 19 indicators. 2 Organizational commitment is measured using three dimensions with nine indicators. 3 Turnover Intention is measured using three dimensions with 12 indicators in this study, The population reached employees 25 outlet the foodhall in Jakarta. Because in accordance with the regulations the thumb in SEM (Hair, Black, Babin, Anderson, \& Tatham, 2006), lack of determination use sample the ratio 5: . Study has 40 parameter; lack of size sample is 200 respondents. The sample method is by using the probability of sampling with proportional who samples random technique.

A method of analysis and testing in this study, which is to measure the impact of the variables in culture and turnover intention variable directly or indirectly through the organization commitment variable. Modelling techniques used and the solution is to use the structural modelling (SEM) a method by data processing analysis tool use Lisrel 8.80 application program.

\section{RESULT AND DISCUSSION}

On the table 2 above, the seven measures obtained have a useful fit model conformity index, namely GFI, RMSEA, NNFI, NFI, RFI, IFI, and CFI. While AGFI is a measure of conformity that has a marginal fit model of conformity index. Thus it can be continued in the next measurement analysis. 
Table 2 - Size of SEM-Model

\begin{tabular}{cccc}
$\begin{array}{c}\text { GOF } \\
\text { Indicator }\end{array}$ & Expecting Size & $\begin{array}{c}\text { Estimate } \\
\text { Result }\end{array}$ & Finding \\
\hline Absolute Fit Size \\
GFI & GFI $>0,90$ & 0,92 & Good Fit \\
RMSEA & RMSEA $<0,08$ & 0,062 & Good Fit \\
& Incremental Fit Size & \\
NNFI & NNFI $>0,90$ & 0,93 & Good Fit \\
NFI & NFI $>0,90$ & 0,94 & Good Fit \\
AGFI & AGFI $>0,90$ & 0,84 & Marginal Fit \\
RFI & RFI $>0,90$ & 0,93 & Good Fit \\
IFI & IFI $>0,90$ & 0,95 & Good Fit \\
CFI & CFI $>0,90$ & 0,95 & Good Fit \\
\hline
\end{tabular}

Source: Processing Result with Lisrel 8.80

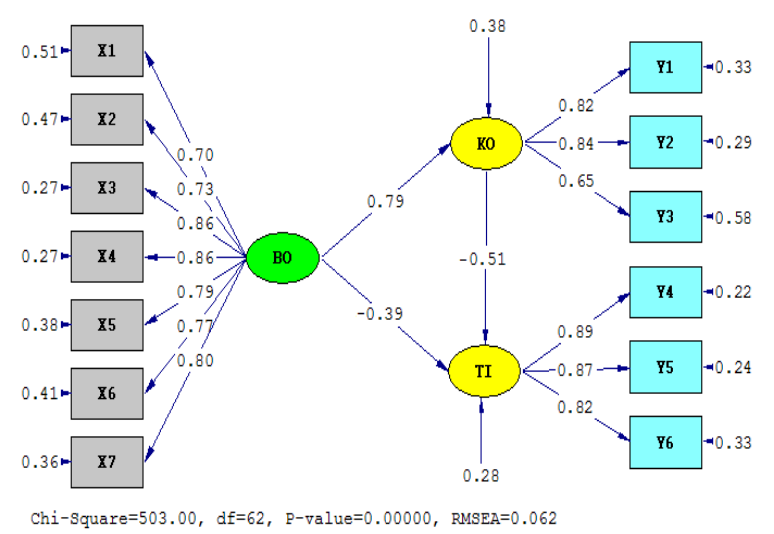

Figure 2 - SEM Model (Standardized)

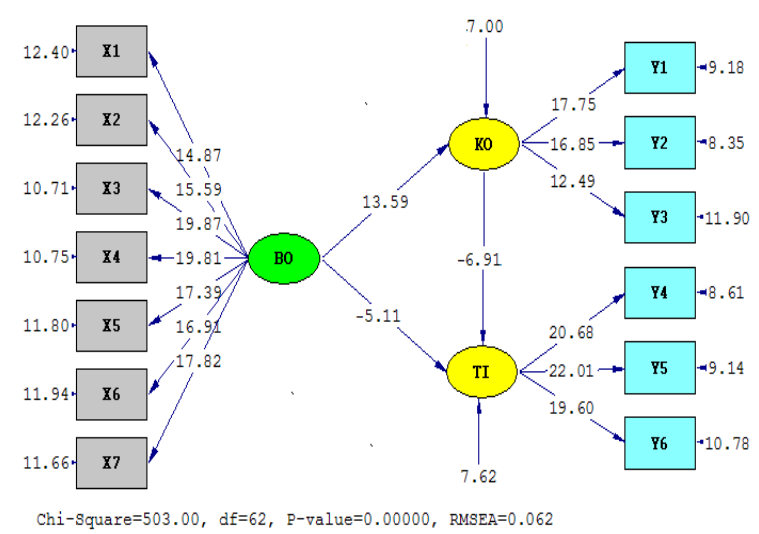

Figure 3 - SEM Model ( $t$-value)

Figure 2 and Figure 3 above show that the analysis of each variable's measurement model shows the organizational culture indicators formulation independent latent variables and organizational commitment and turnover intention dependent latent variables have good validity. This is indicated by all indicators having Standardized Loading Factor ( SLF) $\geq 0.5$ and value values $\geq 1.96$ (at $\alpha=0.05$ ) (Hair et al., 2006). Likewise, both independent and dependent latent variables have good model reliability, shown by all variables having to construct reliability values greater than $0.70(\mathrm{CR}>0.70)$ and variance extract values greater than $0.50(\mathrm{VE}>0.50)$.
Table 3 - Structural Equation Model

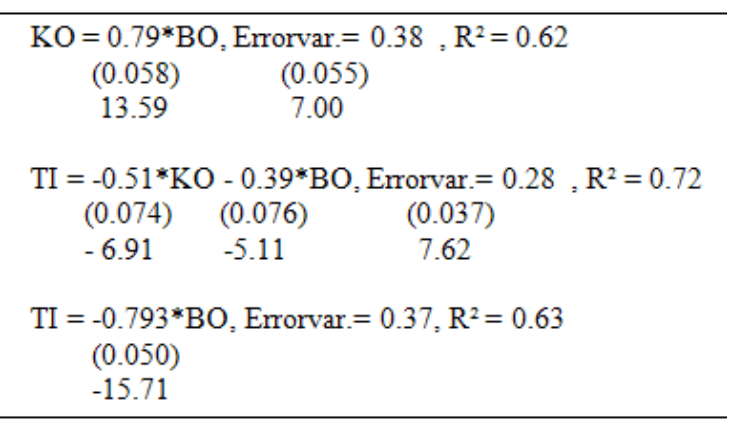

Figure 2, Figure 3, and Table 3 above shows that the structural equation model can be stated as follows:

1. The organizational culture variables have influence on organizational commitment is 0.79 with a t-value of $13.59>1.96$, so it can be said as significant. The contribution of organizational culture's influence on an organizational commitment by $62 \%$. Simultaneously, the organizational culture variables on turnover intention is -0.39 with a t-value of $|-5.11|>1.96$, so it can be said as significant. The influence of organizational culture on turnover intention is $15.21 \%$. Thus, organizational culture is proven to have a positive and significant effect on organizational commitment, and a significant negative on turnover intention or hypothesis is accepted. (Telha et al., 2016) Organization culture understands values and confidence sub units developed in an organization or direct employees who conduct the organization's explanation. (Chu et al., 2016) argued cultural of organizations explain the right way for preparing, thinking, and feeling in a relationship with one another in the system of social. (Telha et al., 2016) states culture as an organizing framework consisting and attitude, cognitive values, norms, behavior, and sharing the wish by members. (Cycyota et al., 2016) shows that organizations understand culture value and confidence in identity. (Sagita et al., 2018) argued that the organization culture is the number of, the ritual, faith, rules typical of, facts and organizations characterize nation. (Limakrisna \& Juju, 2008) stated that the culture is a system to the meaning of value to the base and valued by, organization which serves to create a clear distinction between one organization and, other makes an identity for the organization members, facilitate the emergence of a commitment to, organization collectively improve stability, social system and create meaning-making control mechanisms and guide the practice of attitudes and behavior team members of organization 
(Kreitner \& Kinicki, 2014). According to , there were seven characteristic introductory together can repeat nature and culture organization, 1) innovation and risks, the extent to which employees are is encouraged to be an innovative and risk; 2) attention to detail the extent to which employees expected to show accuracy, analysis, and call attention to detail; 3) from orient, the extent to which the management is focusing on results, not on engineering and the process used to achieve their; 4) orientation, the extent to which management decisions consider the effects of the above the in the organization; 5) orientation the extent to which the team work, held at least not attending individual; 6) aggressiveness, the extent to which aggressive and competitive of relaxed; 7) stability the extent to which the organizations stressed to keep the status quo from Indonesia (S. Robbins \& Judge, 2009).

2. The organizational commitment have influence on turnover intention is -0.51 with a $\mathrm{t}$-value of $|-6.91|>1.96$, so it can be said to be significant. The contribution of organizational commitment on turnover intention is $26.01 \%$. Thus, organizational commitment is proven to have a negative and significant effect on turnover intention, or the second hypothesis is accepted. (Herawati \& Prayekti, 2017) commitment organization is the extent to which employees believe and receive organizations purpose and a desire to remain with organization. (Buchari, 2016) stated how a commitment organization is an intense desire to be a member of certain organizations, a strong desire to try to conform with an organization, confidence, the value and receiving value in individual and organizational goals. While (Bailey et al., 2016) commitment organization is a bond psychological employees to the organization that are characterized by the strong beliefs and receipts for the purpose and the values of the organization, desire to accomplish a purpose organization, and a strong desire for maintain a position them as of members of an organization. (Srivastava \& Kanpur, 2014) stated that the organization to know the level of the employees and organization because of the employees and affect the organization employees. (Mercurio, 2015) see social organization commitment as a willingness to provide energy and loyalty to organizations. The statement shows that commitment is an employee willingness to exert a high level of business at, organization a strong desire to stay with the organization, and the organization goals, mission and values. The same time (Bulut \& Culha, 2010) defines commitment as a situation in which the organization members are bound by the actions and the belief that support their activities and their involvement in the organization. The concept commitment organization defined and measured in different ways.

3. The organizational culture have influence on turnover intention through organizational commitment is -0.403 with a t-value of $|-6.14|>1.96$ (Sobel Test), so it can be said as significant. The organizational culture have influence on turnover intention through organizational commitment is $16.23 \%$. Thus, organizational culture is proven to affect on turnover intention through organizational commitment negatively, or the third hypothesis is accepted.

4. The determination (R2) of organizational culture and organizational commitment simultaneous on employee performance is 0.72 with an F-value of $261.60>3.84$, so it can be significant. The determination (R2) shows that the contribution of organizational culture and organizational commitment simultaneously on turnover intention is $72 \%$. In comparison, $28 \%$ is a massive influence outside the variables studied. The most dominant variable affecting turnover intentions is the organizational commitment variable. Thus, organizational culture and organizational commitment are simultaneously proven to affect on turnover intentions significantly, or the fourth hypothesis is accepted. According to (Nitzsche et al., 2014)an instrument for measuring an organizational culture that promotes the work-life balance of employees. $\backslash n \|$ nnMETHODS: In Study $1(\mathrm{~N}=498$ the purpose of the enter and leave at employees are tendency have or rate at which an employee can leave his organization or voluntarily resigned from his job and judge. (S. P. Robbins \& Judge, 2017) defines the law permanently cessation enter and leave at employees working from the company either by employees he (voluntarily) or done by the company. (Cycyota et al., 2016) the higher satisfaction work and commitment the organization was expected to reduce property and employees to leave those organization.

The test results above show that the organizational culture variable directly influences the turnover intention variable with a coefficient of $(-0.39)$. Organizational culture variables indirectly affect turnover intention through organizational commitment with a coefficient of (-0.4029). 
Organizational culture directly or indirectly through organizational commitment affects turnover intention with a contribution of $63 \%$. However, simultaneously organizational culture and organizational commitment affect turnover intention with a contribution of $72 \%$. This shows that this study's organizational commitment is a partial mediating variable on the influence of organizational culture variables on turnover intention.

The findings of this study to reduce employee turnover intentions at FoodHall in DKI Jakarta, mainly reflected in the low dimension of stop mind, will be able to be lowered if the company can increase the commitment of the organization, mainly reflected in the high dimension of continuity commitment, the commitment of the organization will increase if the company can improve the culture of the organization mainly reflected in the high dimension of the orientation of the results and orientation of the community (Abad et al., 2017; Fletcher, Nutton, \& Brend, 2014; Maes, 2008).

\section{CONCLUSION}

Improving the organization's culture will increase organizational commitment and decrease employee turnover intentions at FoodHall in DKI Jakarta. The most importance in measuring organizational culture is reflected in the orientation of the results and people's orientation dimensions. At the same time, the most dominant dimension in measuring organizational commitment is reflected by the dimension of continuance commitment, especially in terms of the level of loyalty in the company and turnover intention reflected by the dimensions of thoughts of quitting, especially in the level of conformity with the work environment.

Increase in organizational commitment will decrease the turnover intentions of FoodHall employees in DKI Jakarta. The most importance organizational commitment is reflected by the dimension of continuance commitment, especially in terms of customer loyalty. In contrast, the turnover intention is reflected by the dimensions of thoughts of quitting, especially in the level of incompatibility with the work environment.

The improvement of the organization's culture will increase organizational commitment that has implications for the decreased intention of employee turnover in FoodHall in DKI Jakarta.Increase in organizational culture and organizational commitment simultaneously will result in a decrease in employee turnover intention at FoodHall in DKI Jakarta, the commitment of the organization is partly the most dominant in reducing employee turnover intentions, so that the organization's commitment is a variable partial mediation to the influence of the organization's culture on turnover intentions.

\section{Managerial Implications}

The organization's commitment of employees at FoodHall, continuous commitment with indicators of loyalty level in the company, will be able to be improved if FoodHall can improve the culture of the organization, orientation of people with indicators of the level of carrying out tasks according to work procedures and levels in doing the work seriously. Meanwhile, the turnover intentions of FoodHall employees, stop thinking the level of mismatch with thework environment, will bereduced if FoodHall can increase the organizational commitment, continuity commitment of loyalty level to the company, where the commitment of the organization will increase if FoodHall can increase, the orientation of the results and orientation of the person with the indicator of the level of carrying out the task according to the work procedure and the level of doing the work in earnest. Likewise, foodhall employee turnover intentions will be directly reduced, especially in the dimensions of the stopping mind, especially in the level of incompatibility with the work environment by improving the culture of the organization, especially in the dimensions of the orientation of the results and orientation of the person with the indicator of the level of carrying out the task according to the work procedure and the level of doing the work in earnest.

\section{REFERENCES}

Abad, A., Victoria Fernández-Molina, J., Bikandi, J., Ramírez, A., Margareto, J., Sendino, J. \& Willem, H. (2017). Molecular cloning and transcriptional regulation of the Aspergillus nidulans $x \operatorname{lnD}$ gene encoding a betaxylosidase. Annual Review of Phytopathology. https://doi.org/10.1016/j.cell.2016.12.020. 13(5), 132-143.

APRINDO. (2017). Indonesia Posts 3rd-Largest Modern Retail Sales Growth in Asia.

Bailey, A.A., Albassami, F. \& Al-Meshal, S. (2016). The roles of employee job satisfaction and organizational commitment in the internal marketing-employee bank identification relationship. International Journal of Bank Marketing, 34(6), 821-840. https://doi. org/10.1108/IJBM-06-2015-0097

Buchari, R.A. (2016). Implementasi E-Service Pada Organisasi Publik Di Bidang 
Pelayanan Publik di Kelurahan Cibangkong Kecamatan Batununggal Kota Bandung. Sosiohumaniora. 4, (2), 35-47. https://doi. org/10.24198/sosiohumaniora.v18i3.8762.

Bulut, C. \& Culha, O. (2010). The effects of organizational training on organizational commitment.InternationalJournalof Training and Development. 11, (9), 59-70. https:/doi. org/10.1111/j.1468-2419.2010.00360.x.

Chen, J. C. \& Silverthorne, C. (2005). Leadership effectiveness, leadership style and employee readiness. Leadership and Organization Development Journal. 8, (2), 221-234. https:// doi.org/10.1108/01437730510600652.

Chu, J., Leino, A., Pflum, S. \& Sue, S. (2016). Amodel for the theoretical basis of cultural competency to guide psychotherapy. Professional Psychology: Research and Practice, 47, (1), 18-29. https://doi.org/10.1037/pro0000055

Cycyota, C.S., Ferrante, C. J. \& Schroeder, J.M. (2016). Corporate social responsibility and employee volunteerism: What do the best companies do? Business Horizons, 59, (3), 321-329. https://doi. org/10.1016/j.bushor.2016.01.004

Fauzi, Y. (2017). Kuartal I 2017, Penjualan Industri Ritel Melorot 20 Persen.

Fletcher, K., Nutton, J. \& Brend, D. (2014). Attachment, A Matter of Substance: The Potential of Attachment Theory in the Treatment of Addictions. Clinical Social Work Journal. 12(5), 112-124. https://doi. org/10.1007/s10615-014-0502-5.

Hair, J. F., Black, W. C., Babin, B. J., Anderson, R.E. \& Tatham, R. L. (2006). Multivariate Data Analysis (6th Eds.). Prentice Hall.

Hakim, A. \& Hadipapo, A. (2015). Peran Kepemimpinan Dan Budaya Organisasi Terhadap Kinerja Sumber Daya Manusia Di Wawatobi. Ekonomi Bisnis. 1(1), 12-24.

Herawati, J. \& Prayekti, P. (2017). Pengaruh Kepemimpinan Etis Dan Komitmen Organisasional Terhadap Kinerja Karyawan Koperasi Batik Di Jogjakarta. Sosiohumaniora. 4, (1), 87-96. https://doi.org/10.30738/sosio. v1i1.516.

Jin, S., Seo, M.G. \& Shapiro, D.L. (2016). Do happy leaders lead better? Affective and attitudinal antecedents of transformational leadership. Leadership Quarterly, 27, (1), 64-84. https:// doi.org/10.1016/j.leaqua.2015.09.002
Kaur, C. (2015). Quality Of Work Life: A Key To Improve Organizational Performance. Sajems Ns.

Kreitner, R., \& Kinicki, A. (2014). Perilaku Organisasi Organizational Behavior. In 1 .

Liden, R.C., Wayne, S.J., Liao, C., \& Meuser, J.D. (2014). Servant leadership and serving culture: Influence on individual and unit performance. Academy of Management Journal. 21, (7), 3547. https://doi.org/10.5465/amj.2013.0034.

Liem, L. (2018). Analisis Faktor-Faktor Yang Dipertimbangkan Konsumen Dalam Menggunakan Layanan Ovo Di Surabaya, 2, (2), 228-241.

Limakrisna, N. \& Juju, U. (2008). Pengaruh Sinergi, Kredibilitas, Kepemilikan Baru, Budaya, Tata Kelola Perusahaan pada Kinerja Bank Pasca Privatisasi. Trikonomika, 7, (2), 97-105.

Limakrisna, N., Noor, Z.Z. \& Ali, H. (2016). Model of employee performance: The empirical study at civil servants in government of west java province. International Journal of Economic Research. 21, (9), 551-567.

Maes, F. (2008). The international legal framework for marine spatial planning. Marine Policy. 28, (9), 331-345. https://doi.org/10.1016/j. marpol.2008.03.013.

Mercurio, Z. A. (2015). Affective Commitment as a Core Essence of Organizational Commitment: An Integrative Literature Review. Human Resource Development Review. 2, (7), 121-134. https://doi.org/10.1177/1534484315603612. 1

Nitzsche, A., Jung, J., Kowalski, C. \& Pfaff, H. (2014). Validation of the Work-Life Balance Culture Scale (WLBCS). Work, 49, (1), 133142. https://doi.org/10.3233/WOR-131643

Robbins, S. \& Judge, T. (2009). Organizational Behaviour: Concepts, Controversies, Applications. Development.

Robbins, S.P. \& Judge, T.A. (2017). Organizational Behavior, Seventeenth Edition, Global Edition. Pearson Education Limited.

Sagita, A.A., Susilo, H. \& Cahyo, M. (2018). Pengaruh Budaya Organisasi Terhadap Kinerja Karyawan Dengan Motivasi Kerja Sebagai Variabel Mediator (Studi Pada PT Astra Internasional, Tbk-Toyota (Auto2000) Cabang Sutoyo Malang). Jurnal Administrasi Bisnis (JAB), 3, 21-34. 
Srivastava, S. \& Kanpur, R. (2014). A Study On Quality Of Work Life: Key Elements \& It's Implications. IOSR Journal of Business and Management. 19, (5), 411-423. https://doi. org/10.9790/487x-16315459.

Sulmiah, S. (2017). Perkembangan Pasar Modern di Indonesia dan Dampaknya terhadap Pasar Tradisional. Jurnal Latihan. 7, (7), 12-24.
Telha, A., Rodrigues, A., Páscoa, C. \& Tribolet, J. (2016). The Competency Architecture as Error Limiting Element and Efficiency Enhancer in Business Processes. In Procedia Computer Science, 100, 665-670). https://doi. org/10.1016/j.procs.2016.09.209

Valaei, N. \& Rezaei, S. (2016). Job satisfaction and organizational commitment. Management Research Review. 1, (4), 145-156. https://doi. org/10.1108/mrr-09-2015-0216. 